\title{
Mobile Learning Aspects and Readiness
}

\author{
Hana Mohamed Eltayeb \\ Department of Computer science \\ Faculty of Computer Science \& IT, Al- \\ Zaiem Al-Azahri University, Sudan
}

\author{
Mohamed Osman Ali Hegazi \\ Department of Computer science \\ (1) College of Computer Engineering and \\ Science, Salman Bin Abdulaziz University, \\ Saudi Arabia \\ (2) Faculty of Computer Science \& IT, Al-Zaiem \\ Al-Azahri University, Sudan
}

\begin{abstract}
ABSTEACT
This paper provide the aspects of mobile learning by presenting the differences techniques and aspects of using mobile devices in education according to the perspective of researches and studies in this area, it offers a comparison between e-learning and m-learning, a classification of education by mobile devices, and shows the categories of mobile learning. The paper also provides the readiness of mobile learning by presenting the results of study conducted at faculty of Computer Science and Information Technology at Al- Zaiem Al-Azahri University in Sudan.
\end{abstract}

\section{General terms}

Computer application, ICT in education, E-learning, Mlearning

\section{Keyword}

e-learning , m-learning, learning, mobile, distance learning,

\section{INTRODUCTION}

Universities over the past few years have either used the internet to enhance the learning, by providing online access to lecture notes, assignments and additional course related resources, or used it as medium of implementing virtual classroom, due to the revelation of IT technologies and internet attending virtual classroom lecture from remote became possible and available.

Popularity of such distance learning programs highlights the importance of flexibility in education system .Mobile devices and their use in education have extended the idea of flexibility to new frontiers .Mobile learning has different interpretations by several communities. The distinct interpretation is in its focus on learning across contexts and learning with handheld or portable devices(phones,Palms, PDA,Windows CE machaines and iPODS). Thus, mobile learning decreases limitation of learning location with the mobility of general handy devices. Learning with portable technologies, where the focus is on the technology; learning across contexts, where the focus is on the mobility of the learner, interacting with portable or fixed technology. Because most students today have some sort of internet-enabled mobile device (3G cell phone or PDA, smart phone)[14]. M learning means "acquisition of any knowledge and skill through using mobile technology anytime, anywhere that result in alteration of behavior"(Gedden S.J.) Mobile learning is convenient in sense that it is accessible virtually from anywhere, which provides access to all different materials available. M learning also bring strong portability for learning contents[3].
In this paper we are going to study the used of mobile technologies in education, the study will covers the aspects and the readiness of using mobile technologies in education (m-learning).

\section{RELATED WORKS}

Mobile learning recently received considerable attention from researchers. The researches in this area came in diversity, some of them concerning about the possibilities and obstacles, some on the impact of m-learning on education, some concern about the technologies, some about the educational environments, and some on the readiness. This study focus on two areas, the technology and the readiness, in concerning with these two areas there are considerable recent researches work; for example [4] , [9], [12] and [13] in the area of using mobile technologies in education, and [1], [5], and [10] in the area of readiness and case study.

The contribution of this study is that; the study presents the technologies and aspects of the mobile learning from different point of views, it provides these aspects from comparison between m-learning and e-leaning point of views, and also it provides these aspects from categorization points of views. Also the study examines the readiness of m-learning by providing a case study include experiment and survey work. Another contribution of this study is that; it's the first study in, it used one of the Sudanese University as a case study (there are more than 32 high education instituted distributed over $1,800,000 \mathrm{sq} . \mathrm{km}$.), which can conceder it as reference work for this region and "may be" for the under developing countries.

\section{M-LEARNING Vs E-LEARNING}

M-learning also seen as an extension of e-learning where the focus is on the use of mobile devices. Laouris and Laouri (2006) classified the move from e-learning to m-learning as a revolution, because it implies change of mindset when designing and planning learning environments and goals, in additional to implies the change in terminology [8].

According to the scientific conference in m-learning ( MLEARN 2004) the relation between m-learning and elearning can be summarized as[11]:

- m-Learning is a sub-set of e-Learning

- m-Learning is a means to enhance the broader learning experience.

- m-Learning is a method for engaging learners on their own terms especially nontraditional learners or for students who cannot participate in classroom[11]. 
From terminology and the technology point of views mobile learning based on mobile and wireless technology while elearning based on computer technology, that mean the contents of m-learning is adapted to the mobile connectivity, the resource limitation, and the programming concepts. Table 1 shows the differences between e-learning and m-learning in respect of the terminology and the technology

Table 1: Table 1: Differences between e-learning and m-learning environments with respect to methods of terminology and technology

\begin{tabular}{|l|l|}
\hline E-learning & M-learning \\
\hline Computer & Mobile \\
\hline Bandwidth & GPRS, G3, Bluetooth \\
\hline Multimedia & Objects \\
\hline Interactive & Spontaneous \\
\hline Hyperlinked & Connected \\
\hline Collaborative & Networked \\
\hline Media-rich & Lightweight \\
\hline Distance learning & Situated learning \\
\hline More formal & Informal \\
\hline Simulated situation & Realistic situation \\
\hline Hyper learning & $\begin{array}{l}\text { Constructivism, } \\
\text { situationism, and } \\
\text { collaborative }\end{array}$ \\
\hline
\end{tabular}

From communication point of view mobile learning in addition to asynchronous communication provides synchronous communication mechanisms and tools. Table 2 shows differences between e-learning and m-learning in respect of communication

Table 2: Differences between e-learning and $\mathrm{m}$ learning environments with respect to methods communication

\begin{tabular}{|l|l|l|}
\hline Respect in & E-learning & M-learning \\
\hline \multirow{4}{*}{$\begin{array}{l}\text { Communicati } \\
\text { on between } \\
\text { instructor and } \\
\text { student }\end{array}$} & $\begin{array}{l}\text { Time-delayed } \\
\text { (students need } \\
\text { check e- mail } \\
\text { Web sites) }\end{array}$ & $\begin{array}{l}\text { Instant delivery } \\
\text { of e- mails or } \\
\text { SMS, voice } \\
\text { communication, } \\
\text { and social } \\
\text { applications } \\
\text { (wasapps, viber, } \\
\text { [.etc) }\end{array}$ \\
\hline \multirow{5}{*}{$\begin{array}{l}\text { Communicati } \\
\text { on between } \\
\text { student and } \\
\text { student }\end{array}$} & Passive & Instant \\
\cline { 2 - 3 } & Communication & Communication \\
\cline { 2 - 3 } & Asynchronous & Synchronous \\
\cline { 2 - 3 } & Scheduled & Spontaneous \\
\hline & $\begin{array}{l}\text { Face-to-face } \\
\text { collaborations } \\
\text { through } \\
\text { communication } \\
\text { application and } \\
\text { social network } \\
\text { tools }\end{array}$ \\
\cline { 2 - 3 } & $\begin{array}{l}\text { Audio- } \\
\text { teleconference } \\
\text { common }\end{array}$ & $\begin{array}{l}\text { Audio and } \\
\text { video- } \\
\text { conference } \\
\text { possible }\end{array}$ \\
\cline { 2 - 3 } & $\begin{array}{l}\text { Travel time to } \\
\text { reach Internet } \\
\text { site }\end{array}$ & $\begin{array}{l}\text { No geographic } \\
\text { boundaries }\end{array}$ \\
\cline { 2 - 3 } & Dedicated & $\begin{array}{l}\text { No travel time } \\
\text { connectivity }\end{array}$ \\
\cline { 2 - 3 } & Plexible \\
\hline
\end{tabular}

\begin{tabular}{|c|c|c|}
\hline & $\begin{array}{l}\text { time for } \\
\text { Poor } \\
\text { communication } \\
\text { due to } \\
\text { group } \\
\text { consciousness }\end{array}$ & $\begin{array}{l}\text { timings on } \\
\text { communication } \\
\text { Rich due to } \\
\text { one-to-one } \\
\text { communication, } \\
\text { reduced } \\
\text { inhibitions }\end{array}$ \\
\hline
\end{tabular}

In m-learning we can used varieties of methods to evaluate students, for example we can use real-life cases, site experiments, online presentation , pre-test, post-test, and group discussion. Table 3 shows differences between elearning and m-learning in respect of the methods of students evolutions

Table 3: Differences between e-learning and $\mathrm{m}$ learning environments with respect to methods of evaluation

\begin{tabular}{|l|l|}
\hline E-learning & M-learning \\
\hline $\begin{array}{l}\text { 1-to-1 basis possible } \\
\text { Asynchronous and at } \\
\text { times delayed }\end{array}$ & $\begin{array}{l}\text { 1-to-1 basis possible Both } \\
\text { asynchronous } \\
\text { and synchronous }\end{array}$ \\
\hline Mass/standardized & Customized \\
\hline Instruction & Instruction \\
\hline Benchmark-based grading & $\begin{array}{l}\text { Performance \& } \\
\text { improvement-based } \\
\text { grading }\end{array}$ \\
\hline $\begin{array}{l}\text { Simulations \& lab based } \\
\text { experiments }\end{array}$ & $\begin{array}{l}\text { Real-life cases and on the } \\
\text { site experiments }\end{array}$ \\
\hline Paper-based & $\begin{array}{l}\text { Less paper, less printing, } \\
\text { lower cost }\end{array}$ \\
\hline
\end{tabular}

\section{MOBILE LEANING CATEGORIES AND TECHNOLOGIES}

According to Kukulska-Hulme and Traxler [6],[7] , mobile learning can be categorized according to

- Technology-driven mobile learning,

- Portable e-Learning.

- Connected classroom learning .

- Informal, personalised, situated mobile learning .

- Mobile training, performance support .

- Remote, rural or development mobile learning .

- Inclusion, assistivity and diversity

- Large-Scale implementation

Table 4 provide a summary to these categorizes with their technologies.

Software and applications, that has been used in mobile education growth increasingly, now a day most of desktop application has mobile phone versions for example Moodle , Blackboard, Office ... etc. , beside that many mobile application and software tools can be used to enhance the educational process. Table 5 show examples of mobile applications that can be used in m-learning. 
Table 4: Mobile learning categories and their technologies

\begin{tabular}{|c|c|c|c|c|c|c|}
\hline $\begin{array}{l}\text { Aspect of } \\
\text { mobile } \\
\text { learning }\end{array}$ & Networks & Technology & Technology Characteristics & Device & Content & Activities \\
\hline $\begin{array}{l}\text { Portable } \\
\text { e-learning }\end{array}$ & & Cable & $\begin{array}{l}\text { Direct wired connection. } \\
\text { Least complicated, least } \\
\text { flexible. }\end{array}$ & $\begin{array}{l}\text { PDA, iPad, } \\
\text { Smartphone, } \\
\text { flash drive }\end{array}$ & $\begin{array}{l}\text { Instructional material } \\
\text { along with audio and } \\
\text { video lectures, word } \\
\text { documents, email, } \\
\text { internet or wikis.. etc. }\end{array}$ & $\begin{array}{l}\text { Tasks, } \\
\text { Learning, } \\
\text { Assessment }\end{array}$ \\
\hline \multirow{4}{*}{$\begin{array}{l}\text { Classroom } \\
\text { learning }\end{array}$} & \multirow{4}{*}{$\begin{array}{l}\text { Local- } \\
\text { Area } \\
\text { Networks, } \\
\text { rally } \\
\text { internet }\end{array}$} & GSM & $\begin{array}{l}\text { Global System for Mobile - } \\
\text { the major telephone and data } \\
\text { standard used in World }\end{array}$ & \multirow{4}{*}{$\begin{array}{l}\text { laptop } \\
\text { computer } \\
\text { PDA's, } \\
\text { mobile } \\
\text { Phones } \\
\text { cell phones }\end{array}$} & \multirow{4}{*}{$\begin{array}{l}\text { Lecturer Regular, } \\
\text { emails, forum } \\
\text { discussion, } \\
\text { photography, audio and } \\
\text { video recording }\end{array}$} & \multirow{4}{*}{$\begin{array}{l}\text { Quizzes and } \\
\text { assignments, } \\
\text { Interacting with } \\
\text { students/learner } \\
\text { Collaboration }\end{array}$} \\
\hline & & $\mathrm{WiFi}$ & $\begin{array}{l}\text { IEEE standard } 802.11 \text { for } \\
\text { wireless networking, with } \\
\text { several current or coming } \\
\text { standards . }\end{array}$ & & & \\
\hline & & IR & $\begin{array}{l}\text { Infra-Red light - } \\
\text { Inexpensive, but increasingly } \\
\text { out of favor as it requires } \\
\text { line of-Sight }\end{array}$ & & & \\
\hline & & Bluetooth & $\begin{array}{l}\text { An increasingly common } \\
\text { networking standard found } \\
\text { in many devices. Costs } \\
\text { continue to go down and } \\
\text { capability goes up, but it } \\
\text { does have power } \\
\text { requirements. }\end{array}$ & & & \\
\hline \multirow{3}{*}{$\begin{array}{l}\text { Rural } \\
\text { mobile } \\
\text { learning }\end{array}$} & \multirow{3}{*}{$\begin{array}{l}\text { Wide- } \\
\text { Area } \\
\text { Networks }\end{array}$} & WiMax & $\begin{array}{l}\text { A promised wireless, broad- } \\
\text { reach, broadband network. }\end{array}$ & \multirow{3}{*}{$\begin{array}{l}\text { Palms, 3G } \\
\text { cell phone } \\
\text { PDA, mart } \\
\text { phone and } \\
\text { iPODS }\end{array}$} & \multirow{3}{*}{$\begin{array}{l}\text { multimedia format } \\
\text { course, segments to } \\
\text { lectures, Flash-card } \\
\text { trainer, internet or wikis }\end{array}$} & \multirow{3}{*}{$\begin{array}{l}\text { Interact } \\
\text { students to each } \\
\text { other and with } \\
\text { the teacher, off } \\
\text {-line course, } \\
\text { Quizz, } \\
\text { Assignment, } \\
\text { Exam }\end{array}$} \\
\hline & & GPRS & $\begin{array}{l}\text { Code Division Multiple } \\
\text { Access }\end{array}$ & & & \\
\hline & & GSM & $\begin{array}{l}\text { Global System for Mobile - } \\
\text { the major telephone and data } \\
\text { standard used in World }\end{array}$ & & & \\
\hline
\end{tabular}


Table 5 : Examples of mobile applications that can be used in m-learning

\begin{tabular}{|l|l|}
\hline Category & Examples \\
\hline $\begin{array}{l}\text { Mobile learning } \\
\text { management software }\end{array}$ & $\begin{array}{l}\text { MLE, MLE-moodle, MDroid, } \\
\text { LearnEM, Classbook, } \\
\text { Blackboard, Blackboard Mobile, } \\
\text { Blackboard Collaborate .. etc. }\end{array}$ \\
\hline Delivery tools & $\begin{array}{l}\text { Polaris office, officeSuite( Word } \\
\text { document, Pdf,..) video, photo..etc }\end{array}$ \\
\hline $\begin{array}{l}\text { Voice and message } \\
\text { communication } \\
\text { applications }\end{array}$ & $\begin{array}{l}\text { Skype, Viber, Line, Voice } \\
\text { Recorder, Assistant, WhatsApp, } \\
\text {.. etc }\end{array}$ \\
\hline Self learning & $\begin{array}{l}\text { Language learning (ex. learning } \\
\text { Japanese, learning Chinese,.. etc), } \\
\text { Quran Learning, maps, ..etc. }\end{array}$ \\
\hline Virtual Classrooms & $\begin{array}{l}\text { Virtual Classrooms, E3 Virtual } \\
\text { Classrooms, Splashtop, } \\
\text { Classroom, Perculus... etc. }\end{array}$ \\
\hline Blogs & Blogger, WordPress, Feedly ..etc \\
\hline
\end{tabular}

\section{MOBILE LEARNING READINESS}

Mobile technologies can be one of the suitable technologies for developing and delivering the education process hence; mobile learning can be any educational interaction delivered through mobile technology, it is not limited in mobile applications that designed specifically for learning purposes, but also those designed for other used such as maps, geological, data access, self learning tools,... etc. Accordingly using mobile in learning will enhance the learning systems and provide more advantages for the educational environments by bringing the benefit of these technologies to the educational fields.

The question arises here; are the technology and the people ready to move towards mobile learning?

This section tests the readiness of using mobile in learning from two points of views:

1- The availability and the capability of the technologies in implementing educational processing (readiness of the hardware and the software).

2- The readiness of teacher and students in using mobile in learning.

\subsection{Readiness of the technology:}

From the previous sections we can conclude that there are varieties of mobile technologies and applications that can be used in implementing m-learning. These technologies are became more available and more usefully, it became a familiar part of the lifes, most of peoples now a day using mobile phone in talking, sending messages, chatting, taking photograph or and accessing information.

In a survey conducted on sample of 96 students from the faculty of Computer Science and Information Technology at Al-Zaiem Al-Azhari University in Sudan, we found that $100 \%$ of the student has mobile phone (cell phone) $85 \%$ of these mobiles phones are smart phones, $20 \%$ of these students in additions to mobile phone has PDA, or iPad. The survey shows that the students are familiar in using these technologies. The survey also shows that students are used mobile in many university activities such as time table, instance messages, courses materials and group discussion.

The survey almost gave the same result when it conducted to sample of 51 teachers in same faculty.

\subsection{Readiness of the teachers and students}

The paper used the faculty of Computer Science and Information Technology at Al-Zaiem Al-Azhari University in Sudan as case study for examines the readiness of the teachers and students towards using mobile technology in learning.

\subsubsection{Study methodology:}

The study conducted into two ways or mechanisms:

- In the first mechanism we prepare m-learning model using MLE software (figure 1) and implement this model in teaching undergraduate students. The feedback from students shows that $85 \%$ of the Students liked the technology and enjoyed the experience.

The feedback from teachers (51) shows that $72 \%$ of them saw that these methods of teaching is useful and it will succeed, the rest of them $(27 \%)$ saw there is still limitation in using mobile phone in learning such as the limitation in memory size, battery life, and speed.

- In the second mechanism we surveyed all the staff (instructors, teaching assistance, lecturers, assistant professors, and associate professor) at the Faculty of Computer Science and Information Technology at AlZaiem Al-Azhari University in Sudan, the total number of the survey population is 51 .

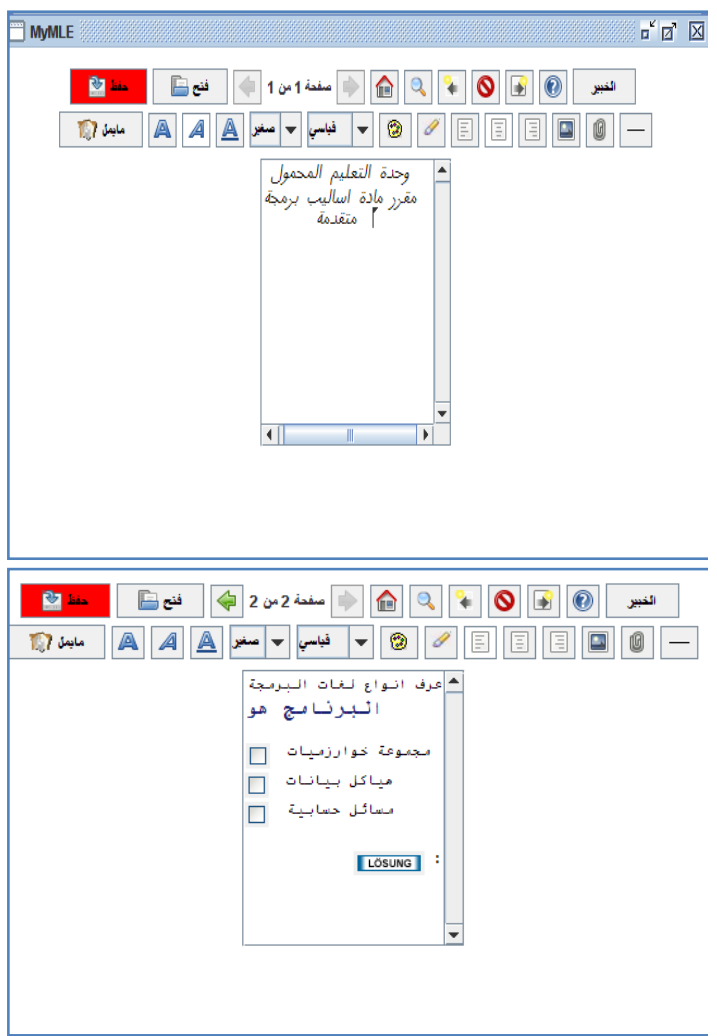

Figure 1: Snapshots of MLE model used in teaching undergraduate students (course lang. is Arabic) 
The authors have analyzed the answers to the qualitative questions in the surveys in an attempt to gain an understanding of how current teachers view the use of mobile devices in learning environments and are they willing to do that? (teachers readiness). The analysis of teacher's perception on m-learning points to the fact that mobile learning is widely embraced by teachers community. The majority of teachers supported the notion that the mobile technologies increase the flexibility of access to resources in learning and that they could work independently of variable resources and $\mathrm{m}$ learning activities can much better engage students in the learning process. Table 6 shows summary of the survey result.

Table 6: A summary of teacher readiness survey results

\begin{tabular}{|c|c|c|c|c|c|c|}
\hline $\begin{array}{l}\text { Item } \\
\text { No }\end{array}$ & $\begin{array}{c}\text { Questionnaire } \\
\text { Indicator }\end{array}$ & $\begin{array}{c}\text { Strongly } \\
\text { agree }\end{array}$ & Agree & undecided & Disagree & $\begin{array}{l}\text { Strongly } \\
\text { Disagree }\end{array}$ \\
\hline 1 & $\begin{array}{l}\text { M-learning helps me in my lessons } \\
\text { delivery }\end{array}$ & $42 \%$ & $27 \%$ & $10 \%$ & $18 \%$ & $3 \%$ \\
\hline 2 & $\begin{array}{l}\text { I advise my colleagues to use m- } \\
\text { learning in their class }\end{array}$ & $35 \%$ & $15 \%$ & $40 \%$ & $5 \%$ & $5 \%$ \\
\hline 3 & $\begin{array}{l}\text { I see that teaching productivity can } \\
\text { be enhanced by the use of mobile } \\
\text { phone in and outside the } \\
\text { classroom. }\end{array}$ & $40 \%$ & $22 \%$ & $28 \%$ & $5 \%$ & $4 \%$ \\
\hline 4 & $\begin{array}{l}\text { M-learning could help college } \\
\text { students to remember their course } \\
\text { details }\end{array}$ & $46 \%$ & $34 \%$ & $14 \%$ & $4 \%$ & $1 \%$ \\
\hline 5 & $\begin{array}{l}\text { Mobile learning can be an effective } \\
\text { method of learning as it can give } \\
\text { immediate support }\end{array}$ & $27 \%$ & $46 \%$ & $20 \%$ & $5 \%$ & $2 \%$ \\
\hline 6 & $\begin{array}{l}\text { With m-learning, students can } \\
\text { achieve more success }\end{array}$ & $29 \%$ & $37 \%$ & $20 \%$ & $10 \%$ & $4 \%$ \\
\hline 7 & $\begin{array}{l}\text { Mobile technology can help } \\
\text { educators in test preparations }\end{array}$ & $42 \%$ & $40 \%$ & $17 \%$ & $1 \%$ & 0 \\
\hline 8 & $\begin{array}{l}\text { Mobile learning will bring new } \\
\text { opportunities of }\end{array}$ & $40 \%$ & $28 \%$ & $29 \%$ & $3 \%$ & $0 \%$ \\
\hline 9 & $\begin{array}{l}\text { Mobile learning is a quicker } \\
\text { method of }\end{array}$ & $32 \%$ & $32 \%$ & $33 \%$ & $1 \%$ & $2 \%$ \\
\hline 10 & $\begin{array}{l}\text { M-learning encourage } \\
\text { collaborative work }\end{array}$ & $31 \%$ & $37 \%$ & $19 \%$ & $19 \%$ & $3 \%$ \\
\hline 11 & $\begin{array}{l}\text { Using M-learning will encourage } \\
\text { my class activities }\end{array}$ & $32 \%$ & $25 \%$ & $28 \%$ & $9 \%$ & $6 \%$ \\
\hline 12 & $\begin{array}{l}\text { I believe that M-learning has a lot } \\
\text { of opportunities for active learning }\end{array}$ & $52 \%$ & $42 \%$ & $5 \%$ & $2 \%$ & $0 \%$ \\
\hline 13 & $\begin{array}{l}\text { I belief that, if my college use M- } \\
\text { Learning, it will increase the } \\
\text { students chances of getting a better } \\
\text { grade }\end{array}$ & $42 \%$ & $37 \%$ & $14 \%$ & $5 \%$ & $2 \%$ \\
\hline 14 & $\begin{array}{l}\text { Mobile learning cannot be used in } \\
\text { Sudan for learning due to } \\
\text { expensive costs. }\end{array}$ & $31 \%$ & $37 \%$ & $15 \%$ & $22 \%$ & $2 \%$ \\
\hline
\end{tabular}

\section{RESULTS}

This paper presents the differences techniques and aspects of using mobile devices in education according to the perspective of researches and studies in this area. The paper provides:

1- A comparison study between e-learning and m-learning.

2- A classification of education by mobile devices.

3- The categories of mobile learning.

The paper also provides the readiness of mobile learning by presenting the results of a study conducted at faculty of Computer Science and Information Technology at Al-Zaiem Al-Azahari University in Sudan.

The paper shows that mobile technologies are ready and available for implementing m-learning, and there is a considerable readiness from the peoples to used mobile in learning. The study shows that $85 \%$ of the student enjoyed the experiment. The survey shows that teachers attitudes toward m-learning were high they are willing to do that (Table 7 and figure 2 and 3 show some statistical results for the survey) These results are consistent with Alwraikat, Mansour A. and Al Tokhaim, Hiam results he [2].

Table 7: statistical results for teachers' survey

\begin{tabular}{|c|l|c|c|c|}
\hline$\#$ & \multicolumn{1}{|c|}{ Question } & mean & std & rank \\
\hline 1. & $\begin{array}{l}\text { M-learning helps me in my } \\
\text { lessons delivery }\end{array}$ & 3.7 & 1.39 & High \\
\hline 2. & $\begin{array}{l}\text { I advise my colleagues to } \\
\text { use m-learning in their class }\end{array}$ & 3.2 & 1.31 & High \\
\hline 3. & $\begin{array}{l}\text { I see that teaching } \\
\text { productivity can be } \\
\text { enhanced by the use of } \\
\text { mobile phone in and } \\
\text { outside the classroom. }\end{array}$ & 3.4 & 1.32 & High \\
\hline
\end{tabular}




\begin{tabular}{|c|l|c|c|c|}
\hline 4. & $\begin{array}{l}\text { M-learning could help } \\
\text { college students to } \\
\text { remember their course } \\
\text { details }\end{array}$ & 3.9 & 1.11 & High \\
\hline 5. & $\begin{array}{l}\text { Mobile learning can be an } \\
\text { effective method of } \\
\text { learning as it can give } \\
\text { immediate support }\end{array}$ & 3.6 & 1.06 & High \\
\hline 6. & $\begin{array}{l}\text { With m-learning, students } \\
\text { can achieve more success }\end{array}$ & 3.5 & 1.14 & High \\
\hline 7. & $\begin{array}{l}\text { Mobile technology can help } \\
\text { educators in test } \\
\text { preparations }\end{array}$ & 3.5 & 1.27 & High \\
\hline 8. & $\begin{array}{l}\text { Mobile learning will bring } \\
\text { new opportunities of } \\
\text { Learning. }\end{array}$ & 4 & 1.14 & High \\
\hline 9. & $\begin{array}{l}\text { Mobile learning is a quicker } \\
\text { method of getting feed back } \\
\text { in learning }\end{array}$ & 3.1 & 1.20 & High \\
\hline 10. & $\begin{array}{l}\text { M-learning encourage } \\
\text { collaborative work }\end{array}$ & 3.9 & 1.10 & High \\
\hline 11. & $\begin{array}{l}\text { Using M-learning will } \\
\text { encourage my class } \\
\text { activities }\end{array}$ & 3.5 & 1.29 & High \\
\hline 12. & $\begin{array}{l}\text { M-learning allows } \\
\text { information to be accessed } \\
\text { at anytime and anywhere } \\
\text { for learning and real tasks }\end{array}$ & 4.4 & 0.80 & High \\
\hline 13. & $\begin{array}{l}\text { I believe that M-learning } \\
\text { has a lot of opportunities } \\
\text { for active learning }\end{array}$ & 3.8 & 1.17 & High \\
\hline 14. & $\begin{array}{l}\text { Mobile learning cannot be } \\
\text { used in Sudan for learning } \\
\text { due to expensive costs. }\end{array}$ & 2.9 & 1.32 & Medi \\
\hline
\end{tabular}

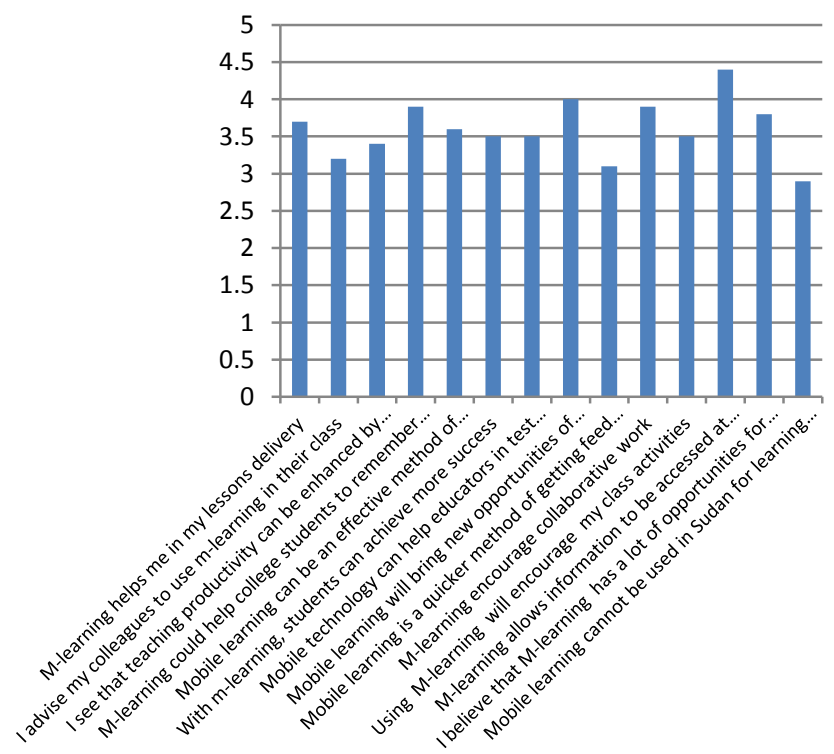

Figure 2: The Mean of teachers' survey

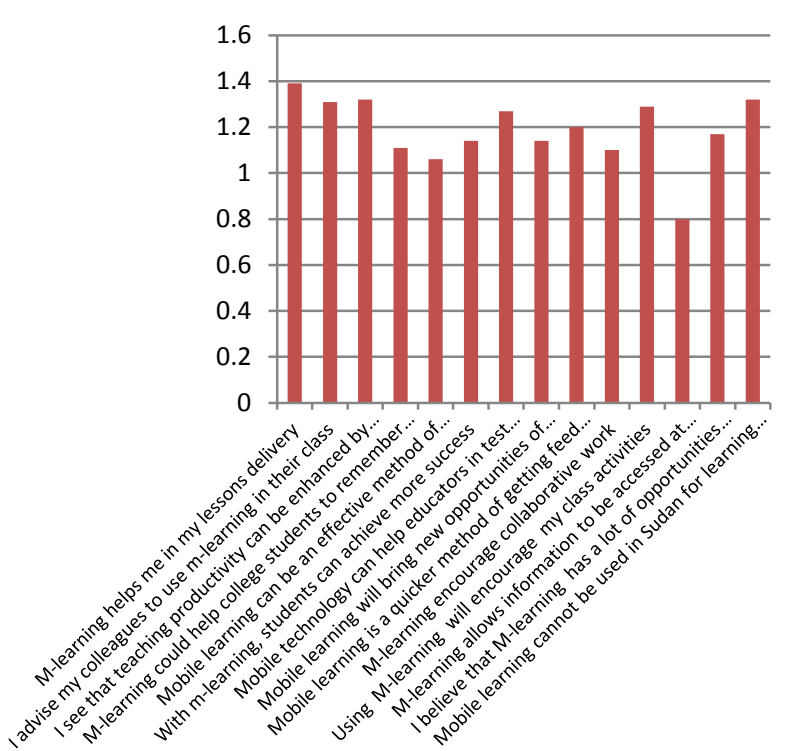

Figure 3: The Standard Deviation of teachers' survey

\section{CONCLUSION}

The paper concludes that the mobile technologies can be one of the suitable technologies for developing and delivering the education process hence; there are varieties of mobile technologies and applications that can be used in implementing m-learning. The study state that these technologies are became more available and more usefully, it became a familiar part of the life, hence, most of peoples now a day using mobile phone in talking, sending messages, chatting, taking photograph or and accessing information.

The paper concludes that using mobile in learning will enhance the learning systems and provide more advantages for the educational environments by bringing the benefit of these technologies to the educational fields.

The study also concludes that mobile technologies are perceived as an effective tool in improving communication and learning. In developing countries (Sudan as a case study)

Finally we can conclude that mobile technologies and its applications are became important part of our life it is involved in most of our life activities and enhance these activates by the advantages of these technologies, therefore using mobile technologies in educational process will be essential to keep pace with the constant evolution and experience the reality.

\section{REFERENCES}

[1] Ali Zuhdi Shaqour. 2014 " Students' Readiness towards M-Learning: A Case Study of Pre-Service Teachers in Palestine" Journal of Educational and Social Research. Vol. 4 No.6. MCSER Publishing, Rome-Italy. September 2014

[2] Alwraikat, Mansour A and Al Tokhaim, Hiam, 2014, “ Exploring the Potential of Mobile Learning Use Among Faculty Members" International Journal of Interactive Mobile Technologies Vol. 8, No 3 pp 4-10(2014)

[3] Anita Hemni, Rajkumar Kewalramani, Kanya Mahavidyalaya, and Jaripatka,Nagpur- "M Learning : Innovative Technology For Learners" 400014 
[4] Chao, H.; Lai, C.; Chen, S.; Huang, Y., "A M-Learning Content Recommendation Service by Exploiting Mobile Social Interactions," Learning Technologies, IEEE Transactions on , vol.7, no.3, pp.221,230, July-Sept. 1 2014

[5] Fahad N. Al-Fahad, 2009 "Students' Attitudes And Perceptions Towards The Effectiveness Of Mobile Learning In King Saud University, Saudi Arabia “ The Turkish Online Journal of Educational Technology TOJET April 2009 ISSN: 1303-6521 volume 8 Issue 2 Article 10.

[6] John Traxler 2009. Learning in a Mobile Age International Journal of Mobile and Blended Learning, 1(1), 1-12, January-March 2009

[7] Kukulska-Hulme, A. \& Traxler, J., 2007. Design for Mobile and Wireless Technologies In H. Beetham \& R. Sharpe (eds). Rethinking Pedagogy for the Digital Age. Routledge; New edition edition (26 April 2007)

[8] Laouris, Y. and Laouri, R. "Can Information and Mobile Technologies serve to close the gap and accelerate development? In Proceedings of MLearn 2006, Alberta, Canada, 22 - 25 October (2006)

[9] María Soledad Ramírez Montoya. 2013, “Integrating Mobile Learning Resources and its Repercussions on Instructional Design and Teaching Processes in the
Virtual Environments" THE GLOBAL JOURNAL OF HUMAN-SOCIAL SCIENCE, VOL 13, NO 7-G, page 18-24. (2013)

[10] Min Liu, Robert Scordino, Renata Geurtz, Cesar Navarrete, Yujung Ko, and Mihyun Lim' 2014," A Look at Research on Mobile Learning in K-12 Education From 2007 to the Present" Journal of Research on Technology in Education, Volume 46, Issue 4, pages 325-372. 2014

[11] Mobile learning anytime everywhere: A book of papers from MLEARN 2004: Conference papers http://www.m-learning.org/arch..

[12] Mohamed Sarrab, Laila Elgamel, and Hamza Aldabbas. 2012 "Mobile Learning(M-learning) and Educational Environments", International Journal of Distributed and Parallel Systems (IJDPS) Vol.3, No.4, July 2012

[13] Shadle, Susan, Ross Perkins, Doug Lincoln, Michael Humphrey, and Eric Landrum."Leading a Multiple Project Mobile Learning Initiative"(Research Bulletin). Louisville, CO: EDUCAUSE Center for Applied Research, April 9, 2013

[14] Victor A.Clincy,and Garima Sogarwal “ Future Technological Approaches To Distance learning “www. citeseerx.ist.psu.edu. 